\title{
Adenosine receptors and fibrosis: a translational review
}

\author{
Bruce N. Cronstein
}

Address: Department of Medicine, Division of Translational Medicine, NYU School of Medicine, 550 First Avenue, New York, NY 10016, USA

Email: bruce.cronstein@nyumc.org

Fl000 Biology Reports 201 I, 3:2I (doi:10.34I0/B3-21)

This is an open-access article distributed under the terms of the Creative Commons Attribution-Non Commercial License (http://creativecommons.org/licenses/by-nc/3.0/legalcode), which permits unrestricted use, distribution, and reproduction in any medium, provided the original work is properly cited. You may not use this work for commercial purposes.

The electronic version of this article is the complete one and can be found at: http://f $1000 . c o m / r e p o r t s / b / 3 / 21$

\begin{abstract}
Adenosine - a purine nucleoside generated extracellularly from adenine nucleotides released by cells as a result of direct stimulation, hypoxia, trauma, or metabolic stress-is a well-known physiologic and pharmacologic agent. Recent studies demonstrate that adenosine, acting at its receptors, promotes wound healing by stimulating both angiogenesis and matrix production. Subsequently, adenosine and its receptors have also been found to promote fibrosis (excess matrix production) in the skin, lungs, and liver, but to diminish cardiac fibrosis. A commonly ingested adenosine receptor antagonist, caffeine, blocks the development of hepatic fibrosis, an effect that likely explains the epidemiologic finding that coffee drinking, in a dose-dependent fashion, reduces the likelihood of death from liver disease. Accordingly, adenosine may be a good target for therapies that prevent fibrosis of the lungs, liver, and skin.
\end{abstract}

\section{Introduction}

Although humans and other mammals have lost, for the most part, the ability to regenerate injured tissue, the capacity to heal wounds is of critical importance for restoring function and, in the skin, maintaining a barrier against the external environment. The processes involved in wound healing include cleaning up the damaged tissue and preventing tissue invasion by microorganisms (inflammation), rebuilding the vascular network in the wounded site and creating a scaffold of connective tissue (granulation tissue formation), surfacing the wound (re-epithelialization), and a much slower process of re-organization of the scar. In some people, such as individuals with diabetes or venous stasis, the process goes awry and the wounds do not heal in a timely fashion or at all. Although tissue repair is effective in re-establishing a barrier, the wound healing process may lead to scarring, fibrosis, and loss of function (as in the case of contractures). Internal organs may similarly be scarred and the fibrosis and loss of architectural integrity may lead to significant organ dysfunction. Moreover, some illnesses, such as scleroderma, are characterized by pathologic fibrosis of the skin and/or internal organs resulting in diffuse skin fibrosis and internal organ dysfunction. Many other ailments, such as liver cirrhosis, may lead to specific organ destruction with resulting fibrosis, scarring, and loss of function.

A variety of factors regulate the wound healing process, ranging from growth factors to small molecules released at the wounded site. One such factor is adenosine, a ubiquitous purine nucleoside that is generated in the extracellular space by dephosphorylation of adenine nucleotides released by cells as a result of metabolic factors, injury, and hypoxia (Figure 1). Adenosine mediates its effects on tissue regeneration and repair via binding and activation of a family of $G$ protein-coupled receptors (adenosine $\mathrm{A}_{1}, \mathrm{~A}_{2 \mathrm{~A}}, \mathrm{~A}_{2 \mathrm{~B}}$, and $\mathrm{A}_{3}$ receptors). In this review, we will discuss the role of adenosine and its receptors in wound healing, fibrosis, and scarring.

\section{Adenosine in wound healing Inflammation}

The first step in wound healing involves the inflammatory response. Neutrophils, mast cells, monocytes/ macrophages, and basophils all play a role in eliminating debris at injured sites, preventing infection of healing tissue and secreting factors that promote recruitment of 
Figure I. Formation of adenosine from adenine nucleotides

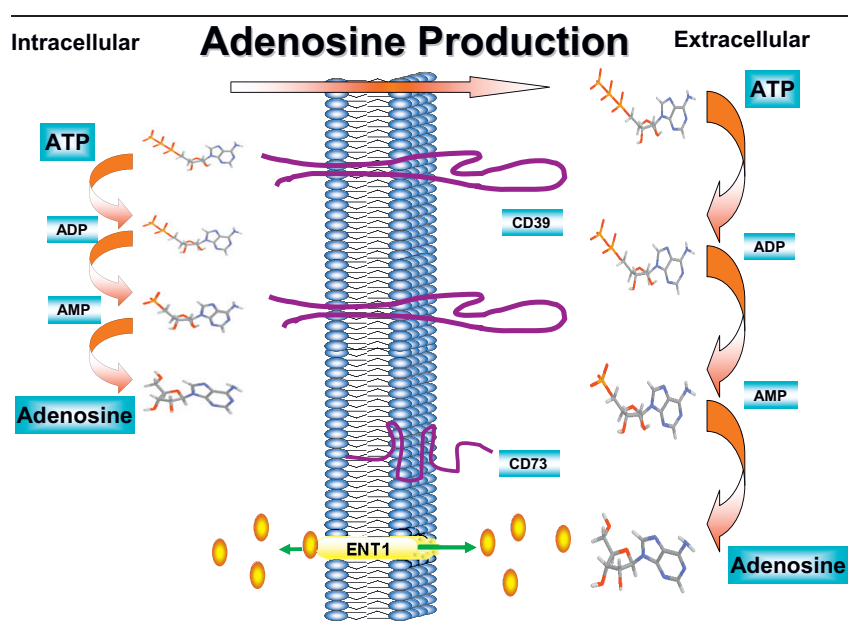

Adenosine is formed both intracellularly and extracellularly from adenine nucleotides, which are sequentially dephosphorylated to adenosine. Intracellular adenosine may be transported into the extracellular space via facilitated transport, and extracellular adenosine is also taken up by cells through the same transporter, equilibrative nucleoside transporter I (ENTI). Two cell surface molecules, CD39 and CD73 (nucleoside triphosphate phosphohydrolase and ecto-5'-nucleotidase, respectively), catalyze the dephosphorylation of adenine nucleotides to adenosine in the extracellular space.

new blood vessels and restoration of injured tissue. Adenosine, acting at its receptors, promotes the transition from a purely inflammatory role to promotion of tissue restoration. Since the first demonstration that adenosine suppresses inflammatory neutrophil functions in 1983 [1], it has been clear that adenosine, acting primarily at $\mathrm{A}_{2 \mathrm{~A}}$ receptors, diminishes the inflammatory functions of both blood-borne and tissue inflammatory cells and even cells of the adaptive immune response (reviewed in [2]). More recent studies demonstrate that adenosine promotes macrophage differentiation into M2-type macrophages [3-5], which help to promote wound healing by releasing factors such as vascular endothelial growth factor (VEGF) that stimulate restoration of tissue at sites of injury (Figure 2).

\section{Angiogenesis}

In 1997, Montesinos and colleagues [6] first reported that adenosine $\mathrm{A}_{2 \mathrm{~A}}$ receptor agonists promote wound healing in mice. The mechanism by which adenosine $\mathrm{A}_{2 \mathrm{~A}}$ receptor stimulation promoted wound healing was not apparent at the time, although endothelial cells and the vasculature were known to produce adenosine from adenine nucleotides, to respond to adenosine by increasing their migration and proliferation, and to be involved in stimulating vascular leakage and promoting coronary vasodilation [7-11]. Thus, it was likely that adenosine, acting at its receptors, directly promoted angiogenesis, a key component of wound healing. Subsequent studies demonstrated that adenosine $\mathrm{A}_{2 \mathrm{~A}}$ receptor activation stimulates endothelial VEGF production via both $\mathrm{A}_{2 \mathrm{~A}}$ and $\mathrm{A}_{2 \mathrm{~B}}$ receptors but that, in wounds, the loss of adenosine $A_{2 A}$ receptors completely abrogated the formation of new blood vessels in the wounds [12-16]. In addition to stimulating production of angiogenic factors, adenosine $A_{2 A}$ receptor activation also inhibits the production of the antiangiogenic factor thrombospondin 1 [15]. Moreover, in addition to the direct effects of adenosine receptors on vascular endothelium, adenosine stimulated macrophages to produce angiogenic factors, such as VEGF $[5,17]$. Finally, adenosine $A_{2 A}$ receptor stimulation promotes recruitment of bone marrow-derived endothelial precursor cells from the circulation [18]. Overall, the evidence seems clear that adenosine $A_{2 A}$ receptor activation is involved in the stimulation of at least one component of wound healing: angiogenesis.

\section{Dermal collagen production}

It was clear from the original description of adenosine receptor promotion of wound healing that adenosine $\mathrm{A}_{2 \mathrm{~A}}$ receptor stimulation also increased matrix production in the healing wounds. Fibroblasts produce matrix, and human foreskin dermal fibroblasts were known to express both adenosine $A_{1}$ and $A_{2}$ receptors [19], which regulate intracellular cAMP (cyclic adenosine monophosphate) levels. Further studies from my group demonstrated that, in these cells, adenosine $A_{2 A}$ receptor stimulation directly promotes collagen production and that, in some situations, this can be a two-edged sword [20]. In a model of diffuse bleomycin-induced dermal fibrosis, we showed that adenosine $\mathrm{A}_{2 \mathrm{~A}}$ receptor stimulation is responsible for promotion of collagen production in the skin, since adenosine $A_{2 A}$ receptor knockout mice or mice treated with an adenosine $A_{2 A}$ receptor antagonist are protected from developing diffuse dermal fibrosis. This was later confirmed in experiments in mice lacking adenosine deaminase. Mice lacking this enzyme accumulate as much as 10-fold increases in adenosine levels and undergo diffuse dermal fibrosis, which is blocked by adenosine $\mathrm{A}_{2 \mathrm{~A}}$ receptor blockade. In addition to direct stimulation of fibroblast collagen production, adenosine also exacerbates collagen production by promoting recruitment of bone marrow-derived fibrocytes from the circulation into the fibrotic skin.

\section{Adenosine and fibrosis Pulmonary fibrosis}

As noted above, mice lacking adenosine deaminase suffer from severe dermal fibrosis. Interestingly, these animals die prematurely from pulmonary inflammation and 
Figure 2. The role of adenosine $A_{2 A}$ and $A_{2 B}$ receptors in wound healing and inflammation

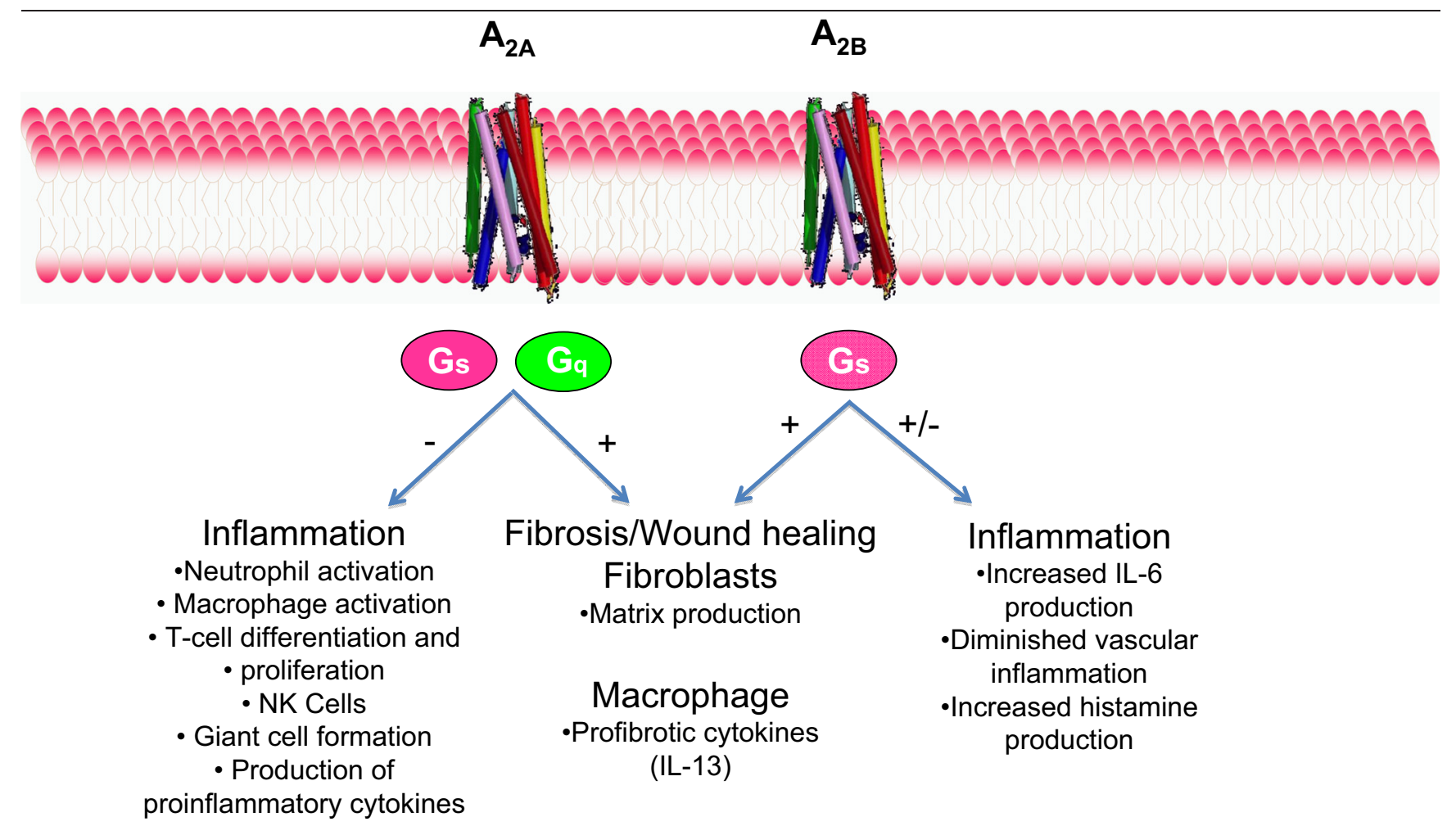

Adenosine in the extracellular space binds to either its $A_{2 A}$ or $A_{2 B}$ receptor, activating the $G$ proteins $G q$ and $G$ s to mediate the effects shown. IL, interleukin; NK cell, natural killer cell.

fibrosis, which is related to increased collagen and interleukin (IL)-13 production [21]. In contrast to the skin, fibrosis and inflammation in the lung appears to be mediated primarily via $\mathrm{A}_{2 \mathrm{~B}}$ receptors and, accordingly, more recent studies demonstrate that adenosine $A_{2 B}$ receptors play a role in the pathogenesis of chronic obstructive pulmonary disease and interstitial fibrosis $[22,23]$. It is likely that the capacity of $A_{2 B}$ receptors to stimulate IL-6 production [22,42] in the lung can stimulate fibrosis indirectly.

\section{Hepatic fibrosis}

Adenosine, generated in the extracellular space from adenine nucleotides by ecto- $5^{\prime}$-nucleotidase, plays a role in the pathogenesis of alcoholic fatty liver $[24,25]$ and, in the setting of chronic alcoholism, the transition of about $20 \%$ of patients to develop hepatic cirrhosis. Recent studies have demonstrated that adenosine, acting at $\mathrm{A}_{2 \mathrm{~A}}$ receptors, stimulates hepatic stellate cell-mediated fibrosis of the liver [26-28] by increasing production of collagen I and III (the collagens present in scar tissue) via two distinct mitogen-activated protein kinase (MAPK)dependent pathways, extracellular signal-regulated kinase 1/2 (ERK1/2) and p38MAPK, respectively [29].
Interestingly, caffeine, the most widely used drug in the world, mediates most of its pharmacologic effects by nonselectively blocking adenosine receptors, including $\mathrm{A}_{2 \mathrm{~A}}$ receptors, and can prevent hepatic fibrosis in animal models [25] and, in a case-control study, patients with a variety of liver ailments [30]. It is, therefore, likely that the pharmacologic effect of caffeine on hepatic fibrosis explains the observation made in numerous epidemiologic studies in different countries that coffee drinking, in a dose-dependent fashion, significantly diminishes death rates due to liver disease [31-40].

\section{Peritoneal fibrosis}

A common complication of abdominal surgery or peritoneal dialysis is peritoneal fibrosis. Although peritoneal fibrosis is usually of little consequence, in some patients, peritoneal fibrosis can lead to bowel obstruction or other problems, so it is encouraging that recent studies in two different animal models of peritoneal fibrosis demonstrate that adenosine $\mathrm{A}_{2 \mathrm{~A}}$ receptor blockade diminishes peritoneal fibrosis and adhesions [41].

\section{Cardiac fibrosis}

Dubey and colleagues [43] have reported that adenosine $\mathrm{A}_{2 \mathrm{~B}}$ receptor activation inhibits cardiac fibroblast 
production of collagen in vitro. In agreement with these original findings, Wakeno and colleagues [44] have reported that adenosine $\mathrm{A}_{2 \mathrm{~B}}$ receptor stimulation diminishes fibrosis and remodeling of the myocardium after infarction.

\section{Conclusion}

Adenosine, a nucleoside that is generated in the extracellular space from adenine nucleotides released at inflamed and hypoxic sites or as a result of metabolic stresses in some tissues and organs, stimulates wound healing, angiogenesis and, in some tissues, under some circumstances, fibrosis. A number of studies demonstrate that stimulated adenosine receptors play different roles in the pathogenesis of fibrosis depending on the tissue. Adenosine $\mathrm{A}_{2 \mathrm{~B}}$ receptors in the heart inhibit fibrosis, whereas these same receptors promote fibrosis in the lungs. In contrast, in the skin, liver, and lungs, adenosine $\mathrm{A}_{2 \mathrm{~A}}$ and $\mathrm{A}_{2 \mathrm{~B}}$ receptors both mediate an increase in fibrosis. It is also striking that different adenosine receptors appear to play a dominant role in fibrosis in different organs; adenosine $\mathrm{A}_{2 \mathrm{~A}}$ receptors are the dominant receptors in the skin, peritoneum, and liver but $\mathrm{A}_{2 \mathrm{~B}}$ receptors are responsible for pulmonary fibrosis. Adenosine blockade at these receptors provides novel targets for new therapies in these difficult clinical settings.

\section{Abbreviations}

IL, interleukin; MAPK, mitogen-activated protein kinase; VEGF, vascular endothelial growth factor.

\section{Competing interests}

Intellectual property: patents held or pending on the use of adenosine A2AR agonists to promote wound healing and use of A2AR antagonists to inhibit fibrosis; use of adenosine A1R antagonists to treat osteoporosis and other diseases of bone; use of adenosine A1R and A2BR antagonists to treat fatty liver; and use of adenosine A2AR agonists to prevent prosthesis loosening.

\section{Acknowledgements}

This work was supported by grants from the National Institutes of Health (AR56672, AR56672S1, and AR54897), the NYU-HHC Clinical and Translational Science Institute (UL1RR029893), and the Vilcek Foundation.

\section{References}

I. Cronstein BN, Kramer SB, Weissmann G, Hirschhorn R: Adenosine: a physiological modulator of superoxide anion generation by human neutrophils. J Exp Med 1983, 158:1160-77.

2. Haskó G, Linden J, Cronstein B, Pacher P: Adenosine receptors: therapeutic aspects for inflammatory and immune diseases. Nat Rev Drug Discov 2008, 7:759-70.
3. Leibovich SJ, Chen JF, Pinhal-Enfield G, Belem PC, Elson G, Rosania A, Ramanathan M, Montesinos C, Jacobson M, Schwarzschild MA, Fink JS, Cronstein B: Synergistic up-regulation of vascular endothelial growth factor expression in murine macrophages by adenosine $\mathbf{A}(2 \mathrm{~A})$ receptor agonists and endotoxin. Am J Pathol 2002, 160:2231-44.

4. Macedo L, Pinhal-Enfield G, Alshits V, Elson G, Cronstein BN, Leibovich SJ: Wound healing is impaired in MyD88-deficient mice: a role for MyD88 in the regulation of wound healing by adenosine A2A receptors. Am J Pathol 2007, I7I:1774-88.

5. Pinhal-Enfield G, Ramanathan M, Hasko G, Vogel SN, Salzman AL, Boons G], Leibovich SJ: An angiogenic switch in macrophages involving synergy between Toll-like receptors $2,4,7$, and 9 and adenosine A(2A) receptors. Am J Pathol 2003, 163:7| I-2I.

6. Montesinos MC, Gadangi P, Longaker M, Sung J, Levine J, Nilsen D, Reibman J, Li M, Jiang CK, Hirschhorn R, Recht PA, Ostad E, Levin RI, Cronstein BN: Wound healing is accelerated by agonists of adenosine A2 (G alpha s-linked) receptors. J Exp Med 1997, 186:1615-20

7. Berne RM, Belardinelli L: Effects of hypoxia and ischaemia on coronary vascular resistance, A-V node conduction and S-A node excitation. Acta Med Scand Suppl 1985, 694:9-19.

FI000 Factor 6

Evaluated by Bruce Cronstein 19 Sep 2011

8. Gawlowski DM, Durán WN: Dose-related effects of adenosine and bradykinin on microvascular permselectivity to macromolecules in the hamster cheek pouch. Circ Res 1986, 58:348-55.

FI000 Factor 6

Evaluated by Bruce Cronstein 19 Sep 2011

9. Des Rosiers C, Nees S: Functional evidence for the presence of adenosine A2-receptors in cultured coronary endothelial cells. Naunyn Schmiedebergs Arch Pharmacol 1987, 336:94-8.

FI000 Factor 6

Evaluated by Bruce Cronstein 19 Sep 2011

10. Bache RJ, Dai XZ, Schwartz JS, Homans DC: Role of adenosine in coronary vasodilation during exercise. Circ Res 1988, 62:846-53.

II. Meininger CJ, Schelling ME, Granger HJ: Adenosine and hypoxia stimulate proliferation and migration of endothelial cells. Am J Physiol 1988, 255:H554-62.

FI000 Factor 6

Evaluated by Bruce Cronstein 19 Sep 201I

12. Grant MB, Tarnuzzer RW, Caballero S, Ozeck MJ, Davis MI, Spoerri PE, Feoktistov I, Biaggioni I, Shryock JC, Belardinelli L: Adenosine receptor activation induces vascular endothelial growth factor in human retinal endothelial cells. Circ Res 1999 , 85:699-706.

FI000 Factor 6

Evaluated by Bruce Cronstein 19 Sep 2011

13. Grant MB, Davis MI, Caballero S, Feoktistov I, Biaggioni I, Belardinelli L: Proliferation, migration, and ERK activation in human retinal endothelial cells through $A(2 B)$ adenosine receptor stimulation. Invest Ophthalmol Vis Sci 200I, 42:2068-73.

FI000 Factor 6

Evaluated by Bruce Cronstein 19 Sep 2011

14. Montesinos MC, Desai A, Chen JF, Yee H, Schwarzschild MA, Fink JS, Cronstein BN: Adenosine promotes wound healing and mediates angiogenesis in response to tissue injury via occupancy of A(2A) receptors. Am J Pathol 2002, 160:2009-18.

15. Desai A, Victor-Vega C, Gadangi S, Montesinos MC, Chu CC, Cronstein BN: Adenosine A2A receptor stimulation increases angiogenesis by down-regulating production of the antiangiogenic matrix protein thrombospondin I. Mol Pharmacol 2005, 67:1406-13. 
16. Ryzhov S, McCaleb JL, Goldstein AE, Biaggioni I, Feoktistov I: Role of adenosine receptors in the regulation of angiogenic factors and neovascularization in hypoxia. J Pharmacol Exp Ther 2007, 320:565-72.

FI000 Factor 6

Evaluated by Bruce Cronstein 19 Sep 2011

17. Leibovich SJ, Chen JF, Pinhal-Enfield G, Belem PC, Elson G, Rosania A, Ramanathan M, Montesinos C, Jacobson M, Schwarzschild MA, Fink JS, Cronstein B: Synergistic up-regulation of vascular endothelial growth factor expression in murine macrophages by adenosine $\mathbf{A}(2 \mathrm{~A})$ receptor agonists and endotoxin. Am J Pathol 2002, 160:2231-44.

18. Montesinos MC, Shaw JP, Yee H, Shamamian P, Cronstein BN: Adenosine $A(2 A)$ receptor activation promotes wound neovascularization by stimulating angiogenesis and vasculogenesis. Am J Pathol 2004, 164:1887-92.

19. Ahmed AH, Jacobson KA, Kim J, Heppel LA: Presence of both AI and $A 2 a$ adenosine receptors in human cells and their interaction. Biochem Biophys Res Commun 1995, 208:87I-8.

FI000 Factor 6

Evaluated by Bruce Cronstein 19 Sep 2011

20. Chan ES, Fernandez P, Merchant AA, Montesinos MC, Trzaska S, Desai A, Tung CF, Khoa DN, Pillinger MH, Reiss AB, Tomic-Canic M, Chen JF, Schwarzschild MA, Cronstein BN: Adenosine A2A receptors in diffuse dermal fibrosis: pathogenic role in human dermal fibroblasts and in a murine model of scleroderma. Arthritis Rheum 2006, 54:2632-42.

21. Blackburn MR, Lee CG, Young HW, Zhu Z, Chunn JL, Kang MJ, Banerjee SK, Elias JA: Adenosine mediates IL-13-induced inflammation and remodeling in the lung and interacts in an IL-I3-adenosine amplification pathway. J Clin Invest 2003, I I 2:332-44.

FI000 Factor 6

Evaluated by Bruce Cronstein 19 Sep 201I

22. Schneider DJ, Lindsay JC, Zhou Y, Molina JG, Blackburn MR: Adenosine and osteopontin contribute to the development of chronic obstructive pulmonary disease. FASEB J 2010, 24:70-80.

FI000 Factor 6

Evaluated by Bruce Cronstein 19 Sep 2011

23. Ma B, Blackburn MR, Lee CG, Homer RJ, Liu W, Flavell RA, Boyden L, Lifton RP, Sun CX, Young HW, Elias JA: Adenosine metabolism and murine strain-specific IL-4-induced inflammation, emphysema, and fibrosis. J Clin Invest 2006, I 16:1274-83.

FI000 Factor 6

Evaluated by Bruce Cronstein 19 Sep 2011

24. Peng Z, Borea PA, Varani K, Wilder T, Yee H, Chiriboga L, Blackburn MR, Azzena G, Resta G, Cronstein BN: Adenosine signaling contributes to ethanol-induced fatty liver in mice. J Clin Invest 2009, I 19:582-94.

25. Peng Z, Fernandez P, Wilder T, Yee H, Chiriboga L, Chan ES, Cronstein BN: Ecto-5'-nucleotidase (CD73) -mediated extracellular adenosine production plays a critical role in hepatic fibrosis. FASEB J 2008, 22:2263-72.

26. Chan ES, Montesinos MC, Fernandez P, Desai A, Delano DL, Yee $\mathrm{H}$, Reiss $A B$, Pillinger MH, Chen JF, Schwarzschild MA, Friedman SL, Cronstein $B N$ : Adenosine $A(2 A)$ receptors play a role in the pathogenesis of hepatic cirrhosis. $\mathrm{Br} J$ Pharmacol 2006, 148: I 144-55.

27. Sohail MA, Hashmi AZ, Hakim W, Watanabe A, Zipprich A, Groszmann RJ, Dranoff JA, Torok NJ, Mehal WZ: Adenosine induces loss of actin stress fibers and inhibits contraction in hepatic stellate cells via Rho inhibition. Hepatology 2009, 49:185-94.

FI000 Factor 6

Evaluated by Bruce Cronstein 19 Sep 2011

28. Hashmi AZ, Hakim W, Kruglov EA, Watanabe A, Watkins W, Dranoff JA, Mehal WZ: Adenosine inhibits cytosolic calcium signals and chemotaxis in hepatic stellate cells. Am J Physiol Gastrointest Liver Physiol 2007, 292:G395-40I.

FI000 Factor 6

Evaluated by Bruce Cronstein 19 Sep 2011

29. Che J, Chan ES, Cronstein BN: Adenosine A2A receptor occupancy stimulates collagen expression by hepatic stellate cells via pathways involving protein kinase $A$, Src, and extracellular signal-regulated kinases I/2 signaling cascade or p38 mitogen-activated protein kinase signaling pathway. Mol Pharmacol 2007, 72:1626-36.

30. Tofovic SP, Salah EM, Jackson EK, Melhem M: Early renal injury induced by caffeine consumption in obese, diabetic ZSFI rats. Ren Fail 2007, 29:89|-902

FI000 Factor 6

Evaluated by Bruce Cronstein 19 Sep 2011

3I. Klatsky AL, Morton C, Udaltsova N, Friedman GD: Coffee, cirrhosis, and transaminase enzymes. Arch Intern Med 2006, 166: $1190-5$.

FI000 Factor 6

Evaluated by Bruce Cronstein 19 Sep 2011

32. Higdon JV, Frei B: Coffee and health: a review of recent human research. Crit Rev Food Sci Nutr 2006, 46:101-23.

FI000 Factor 6

Evaluated by Bruce Cronstein 19 Sep 2011

33. Ruhl CE, Everhart JE: Coffee and tea consumption are associated with a lower incidence of chronic liver disease in the United States. Gastroenterology 2005, I29:1928-36.

FI000 Factor 6

Evaluated by Bruce Cronstein 19 Sep 2011

34. Tverdal A, Skurtveit S: Coffee intake and mortality from liver cirrhosis. Ann Epidemiol 2003, 13:419-23.

FI000 Factor 6

Evaluated by Bruce Cronstein 19 Sep 2011

35. Corrao G, Zambon A, Bagnardi V, D'Amicis A, Klatsky A; Collaborative SIDECIR Group: Coffee, caffeine, and the risk of liver cirrhosis. Ann Epidemiol 200 I, I I:458-65.

FI000 Factor 6

Evaluated by Bruce Cronstein 19 Sep 2011

36. Sharp DS, Everhart JE, Benowitz NL: Coffee, alcohol, and the liver. Ann Epidemiol 1999, 9:391-3.

FI000 Factor 6

Evaluated by Bruce Cronstein 19 Sep 2011

37. Tanaka K, Tokunaga S, Kono S, Tokudome S, Akamatsu T, Moriyama T, Zakouji H: Coffee consumption and decreased serum gamma-glutamyltransferase and aminotransferase activities among male alcohol drinkers. Int J Epidemiol 1998 , 27:438-43.

FI000 Factor 6

Evaluated by Bruce Cronstein 19 Sep 201I

38. Corrao G, Lepore AR, Torchio P, Valenti M, Galatola G, D'Amicis A, Aricó $S$, di Orio $F$ : The effect of drinking coffee and smoking cigarettes on the risk of cirrhosis associated with alcohol 
consumption. A case-control study. Provincial Group for the Study of Chronic Liver Disease. Eur J Epidemiol 1994, 10:657-64.

FI000 Factor 6

Evaluated by Bruce Cronstein 19 Sep 2011

39. Klatsky AL, Armstrong MA, Friedman GD: Coffee, tea, and mortality. Ann Epidemiol 1993, 3:375-8I.

FI000 Factor 6

Evaluated by Bruce Cronstein 19 Sep 2011

40. Klatsky AL, Armstrong MA: Alcohol, smoking, coffee, and cirrhosis. Am J Epidemiol 1992, I36:1248-57.

FI000 Factor 6

Evaluated by Bruce Cronstein 19 Sep 2011

41. Nakav S, Kachko L, Vorobiov M, Rogachev B, Chaimovitz C, Zlotnik M, Douvdevani A: Blocking adenosine A2A receptor reduces peritoneal fibrosis in two independent experimental models. Nephrol Dial Transplant 2009, 24:2392-9.

FI000 Factor 6

Evaluated by Bruce Cronstein 19 Sep 2011
42. Zhou Y, Murthy JN, Zeng D, Belardinelli L, Blackburn MR: Alterations in adenosine metabolism and signaling in patients with chronic obstructive pulmonary disease and idiopathic pulmonary fibrosis. PLoS One 2010, 5:e9224.

FI000 Factor 6

Evaluated by Bruce Cronstein 19 Sep 2011

43. Dubey RK, Gillespie DG, Jackson EK: Adenosine inhibits collagen and protein synthesis in cardiac fibroblasts: role of A2B receptors. Hypertension 1998, 31:943-8.

FI000 Factor 6

Evaluated by Bruce Cronstein 19 Sep 2011

44. Wakeno M, Minamino T, Seguchi $O$, Okazaki $H$, Tsukamoto $O$, Okada K, Hirata A, Fujita M, Asanuma H, Kim J, Komamura K, Takashima S, Mochizuki N, Kitakaze M: Long-term stimulation of adenosine A2b receptors begun after myocardial infarction prevents cardiac remodeling in rats. Circulation 2006, I 1 4: 1923-32.

FI000 Factor 6

Evaluated by Bruce Cronstein 19 Sep 2011 